\title{
Influence of Carbohydrate Source on Ruminal Fermentation Characteristics, Performance, and Microbial Protein Synthesis in Dairy Cows
}

\author{
G. N. Gozho and T. Mutsvangwa ${ }^{1}$ \\ Department of Animal and Poultry Science, University of Saskatchewan, Saskatoon, Saskatchewan, Canada S7N 5A8
}

\begin{abstract}
Eight multiparous Holstein cows $(676 \pm 57 \mathrm{~kg}$ of body weight; $121 \pm 17 \mathrm{~d}$-in-milk) were used in a replicated $4 \times 4$ Latin square design to determine the effects of 4 sources of carbohydrate on milk yield and composition, ruminal fermentation, and microbial $\mathrm{N}$ flow to the duodenum. Four cows in one of the Latin squares were fitted with permanent ruminal cannulae. Diets contained (DM basis) $50 \%$ forage in combinations of alfalfa hay and barley silage, and 50\% concentrate. The concentrate portion of the diets contained barley, corn, wheat, or oats grain as the primary source of carbohydrate. Intake of DM ranged from 24.0 to $26.2 \mathrm{~kg} / \mathrm{d}$, and it tended to be lower in cows fed the wheat-based diet compared with those fed the barley-based diet; consequently, milk yield tended to be lower in cows fed the wheat-based diet compared with those fed the barleybased diet. Cows fed the barley- or wheat-based diets had a lower milk fat content compared with those fed the corn-based diet. Ruminal fermentation characteristics were largely unaffected by the source of dietary carbohydrate, with similar ruminal $\mathrm{pH}$ and volatile fatty acid and ammonia concentrations for the first 6 $\mathrm{h}$ after the morning feeding. Dietary treatment did not affect total tract apparent digestibility of DM, organic matter, and neutral detergent fiber; however, total tract apparent digestibility of starch in cows fed the oatsbased diet was higher compared with those fed the cornand wheat-based diets. Nitrogen that was used for productive purposes (i.e., $\mathrm{N}$ secreted in milk + $\mathrm{N}$ apparently retained by the cow) tended to be lower in cows fed the wheat-based diet compared with cows fed the barley-, corn-, or oats-based diets. Urinary purine derivative (PD) excretion was similar in cows fed the barley-, corn-, and wheat-based diets; however, purine derivative excretion was higher in cows fed the barley-based diet compared with those fed the oats-based diet. Conse-
\end{abstract}

Received October 29, 2007.

Accepted April 2, 2008.

${ }^{1}$ Corresponding author: tim.mutsvan@usask.ca quently, estimated microbial $\mathrm{N}$ flow to the duodenum was $49 \mathrm{~g} / \mathrm{d}$ higher in cows fed the barley-based diet compared with those fed the oats-based diet. Improved production performance with corn and barley diets appeared to be due to greater nutrient absorption than in cows fed oats and wheat diets, rather than improved nutrient utilization efficiency.

Key words: dairy cow, nonstructural carbohydrate, rumen fermentation, rumen degradable starch

\section{INTRODUCTION}

In ruminants, the energy derived from carbohydrate digestion in the rumen drives microbial protein synthesis and, thus, contributes toward the animal's protein requirements (Koenig et al., 2003). Typically, carbohydrates make up 70 to $80 \%$ of the dairy cow's diet (Nocek and Russell, 1988). In western Canada and the United States, dairy cow diets usually contain barley, corn, wheat, or oats as the main carbohydrate source because they are a cost-effective source of digestible energy. Starch is the major nutrient that provides energy from these cereal grains. These cereal grains differ in their starch content, with wheat containing (DM basis) $77 \%$ starch, corn $72 \%$, and barley and oats 57 to 58\% (see review by Huntington, 1997). Differences also exist among these cereal grains in their rates and extents of ruminal starch degradation, with 55 to $70 \%$ of corn starch, 80 to $90 \%$ of barley and wheat starch, and 92 to $94 \%$ of oats starch being digested in the rumen (Huntington, 1997). In principle, the rate and extent of fermentation of dietary carbohydrates in the rumen are important parameters that determine nutrient supply to the animal (Hall, 2004).

Meta-analyses of studies on the impact of dietary carbohydrate content in dairy cow diets showed that greater dietary concentration of nonstructural carbohydrates increases the utilization of ruminal ammonia$\mathrm{N}$ for microbial protein synthesis (Nocek and Russell, 1988; Hoover and Stokes, 1991; Nocek and Tamminga, 1991). In a more recent review of the literature by Cabrita et al. (2006), more ruminally degradable starch 
increased microbial $\mathrm{N}$ supply in 2 studies and had no effect in 5 studies. Increasing ruminally available energy content of diets for dairy cows has potential to enhance milk production through increased metabolizable nutrient supply, including that from increasing microbial protein synthesis in the rumen. Because barley, corn, wheat, or oats differ in their rates and extents of ruminal starch digestion, our hypothesis was that their ability to support microbial protein synthesis in the rumen would differ. Therefore, the objective of the study was to evaluate the effect of dietary inclusion of barley, corn, wheat, or oats as the principal source of starch on microbial $\mathrm{N}$ flow to the duodenum, performance, and $\mathrm{N}$ retention in dairy cows.

\section{MATERIALS AND METHODS}

\section{Animals and Experimental Design}

Eight multiparous Holstein cows $(676 \pm 57 \mathrm{~kg}$ of BW; $121 \pm 17$ DIM) were used in a replicated $4 \times 4$ Latin square design with 21 -d periods and 4 dietary treatments. Four cows in 1 Latin square were fitted with permanent ruminal cannulae and were used in a metabolic study to investigate dietary effects on ruminal fermentation patterns and total tract diet digestibility. Cows were housed in individual tie-stalls and had free access to drinking water throughout the trial. Animals were cared for and handled in accordance with the Canadian Council on Animal Care regulations, and the University of Saskatchewan Animal Care Committee approved their use for this experiment (UCACS Protocol No. 20040048).

\section{Experimental Treatments, Feeding Management, and Sample Collection}

The 4 dietary treatments examined were different cereal grains as the major source of starch, with the concentrate portion of the diet containing barley, corn, wheat, or oats. All cereal grains were dry rolled. Experimental diets contained between 28 and $31 \%$ of cereal grain as the major source of starch. The ingredient composition and chemical analysis of the experimental diets is shown in Table 1. Barley, corn, wheat, and oats were selected because dairy cow diets in western Canada and the United States typically contain any one or combinations of these cereal grains as the principal source of energy. Additionally, starch content and the rates and extents of ruminal starch degradation differ with the species of cereal grain. The main protein sources for the experimental diets were whole canola seed, canola meal, wheat distillers dried grains, and corn gluten meal (Table 1). Whole canola seed was added to the concentrate such that experimental diets would contain 5 to $6 \%$ fat, on a DM basis. The forage to concentrate ratio of the diets was 50:50. The forage component of the diet was a mixture of barley silage and chopped alfalfa hay. The diets were formulated to be isonitrogenous at $2.72 \% \mathrm{~N}(17 \% \mathrm{CP})$. During each data collection period, particle size distribution was determined for the forage mixture using the Penn State Particle Separator (PSPS) as described by Heinrichs (1996). The PSPS used was equipped with 3 screens (19.0, 8.0, and $1.18 \mathrm{~mm}$ ) and a bottom pan. Briefly, approximately 150 to $200 \mathrm{~g}$ of the forage mixture was placed on the top screen of the PSPS. The PSPS was shaken as described by Heinrichs (1996). As-fed forage fractions retained on each screen and the bottom pan were then weighed to determine particle size distribution.

Each 21-d experimental period consisted of $14 \mathrm{~d}$ of dietary adaptation and $7 \mathrm{~d}$ (d 15 to 21 ) for sample and data collection. Experimental diets were fed twice daily at 0800 and $1530 \mathrm{~h}$ as TMR for ad libitum intake. During the 7-d sample and data collection period, individual cow feed intake was recorded daily. Samples of TMR and orts were collected daily, stored at $-20^{\circ} \mathrm{C}$, and composited per cow for each experimental period. Composite samples of orts were based on daily amounts of orts for each cow. After the experiment, pooled samples of TMR and orts were dried at $55^{\circ} \mathrm{C}$ in an oven for $48 \mathrm{~h}$, ground through a 1-mm screen using a Christy-Norris mill (Christy and Norris Ltd., Chelmsford, UK), and analyzed for DM, OM, ether extract, Kjeldahl N (AOAC, 1990), ADF (Van Soest et al., 1991), NDF with heatstable $\alpha$-amylase and sodium sulfite (Van Soest et al., 1991). Starch concentration of TMR, orts, and fecal samples was analyzed using a starch assay kit (Megazyme International Ireland Ltd., Wicklow, Ireland; McCleary et al., 1994).

Cows were milked twice daily at 0500 and $1500 \mathrm{~h}$, and milk weights were recorded during the 7-d data collection period. Milk production was converted to $3.5 \% \mathrm{FCM}$ as $(0.434 \times \mathrm{kg}$ of milk $)+(16.216 \times \mathrm{kg}$ of milk fat). On d 17, 18, and 19 of each experimental period, milk samples were collected from morning and afternoon milkings into plastic vials that contained a preservative (2-bromo-2-nitropropane-1-2-diol). Milk samples were then pooled daily based on milk yield. Pooled samples were immediately submitted to the Provincial Milk Testing Laboratory (Saskatchewan Agriculture, Food and Rural Revitalization, Regina, Saskatchewan, Canada) for compositional analysis. Milk samples were analyzed for CP, lactose, and fat using a near infrared analyzer (Foss System 4000, Foss Electric, Hillerød, Denmark) according to AOAC (1990).

Blood samples were collected at $4 \mathrm{~h}$ postfeeding on $\mathrm{d}$ 19 and 20 of the experimental period from the coccygeal 
Table 1. Ingredient composition and chemical analysis of experimental TMR fed to lactating dairy cows

\begin{tabular}{|c|c|c|c|c|}
\hline \multirow[b]{2}{*}{ Item } & \multicolumn{4}{|c|}{ Source of carbohydrate in the diet } \\
\hline & Barley & Corn & Wheat & Oats \\
\hline \multicolumn{5}{|l|}{ TMR ingredient, \% of diet DM } \\
\hline Barley silage & 29.8 & 30.1 & 32.1 & 30.0 \\
\hline Alfalfa hay & 18.1 & 18.3 & 19.5 & 18.2 \\
\hline Barley & 31.1 & - & - & - \\
\hline Corn & - & 28.7 & - & - \\
\hline Wheat & - & - & 32.8 & - \\
\hline Oats & - & - & - & 30.5 \\
\hline Canola seed & 5.4 & 4.0 & 5.8 & 3.5 \\
\hline Canola meal & 3.8 & 5.5 & 1.9 & 5.5 \\
\hline Soybean meal & 5.7 & 7.3 & 1.4 & 6.2 \\
\hline Corn gluten meal & 1.0 & 1.0 & 1.1 & 1.0 \\
\hline Wheat distillers dried grains & 2.0 & 2.0 & 2.1 & 2.0 \\
\hline Canola oil & 0.41 & 0.42 & 0.44 & 0.42 \\
\hline Molasses & 0.42 & 0.42 & 0.45 & 0.42 \\
\hline Mineral and vitamin premix ${ }^{1}$ & 1.7 & 1.7 & 1.8 & 1.7 \\
\hline Salt & 0.34 & 0.35 & 0.37 & 0.35 \\
\hline Dynamate $^{2}$ & 0.15 & 0.16 & 0.17 & 0.16 \\
\hline \multicolumn{5}{|l|}{ Chemical composition } \\
\hline DM, \% & 54.5 & 54.3 & 54.3 & 55.1 \\
\hline $\mathrm{CP}, \%$ of DM & 17.6 & 17.2 & 17.4 & 17.3 \\
\hline $\mathrm{ADF}, \%$ of $\mathrm{DM}$ & 26.8 & 25.9 & 26.5 & 27.3 \\
\hline $\mathrm{NDF}, \%$ of $\mathrm{DM}$ & 32.7 & 32.9 & 33.0 & 35.7 \\
\hline Starch, \% of DM & 19.2 & 21.8 & 22.4 & 15.2 \\
\hline Ether extract, \% of DM & 5.3 & 5.4 & 5.4 & 5.8 \\
\hline $\mathrm{NE}_{\mathrm{L}},{ }^{3} \mathrm{Mcal} / \mathrm{kg}$ of $\mathrm{DM}$ & 1.6 & 1.6 & 1.6 & 1.6 \\
\hline
\end{tabular}

${ }^{1}$ Contained (/kg of premix; DM basis): 330,000 IU of vitamin A, 60,000 IU of vitamin D, 1,000 IU of vitamin E, $16 \% \mathrm{Ca}, 8.5 \% \mathrm{P}, 6.3 \% \mathrm{Na}, 4.5 \% \mathrm{Mg}, 2,100 \mathrm{mg} \mathrm{Zn}, 1,500 \mathrm{mg} \mathrm{Mn}, 535 \mathrm{mg} \mathrm{Cu}, 12 \mathrm{mg}$ Se, $45 \mathrm{mg} \mathrm{I}$.

${ }^{2}$ Dynamate (Eastern Minerals Inc., Henderson, NC) contained $18 \% \mathrm{~K}, 11 \% \mathrm{Mg}$, and $22 \% \mathrm{~S}$.

${ }^{3}$ Calculated from NRC (2001).

vein of each animal using 2.5 -cm, 20 -ga needles and collected into 10-mL heparin-containing tubes (Becton Dickinson, Rutherford, NJ). Plasma was prepared immediately after collection by centrifugation of blood at $1,000 \times g$ for $15 \mathrm{~min}$ and then stored at $-20^{\circ} \mathrm{C}$ until further analysis. Plasma urea-N (PUN) was determined colorimetrically using the diacetyl monoxime method (Procedure No. 0580; Stanbio Laboratory, Boerne, TX). Plasma glucose concentration was measured with a glucose oxidase method (Procedure No. 1070; Stanbio Laboratory).

\section{Ruminal Fermentation Characteristic, Total Tract Diet Digestibility, and N Balance}

Ruminal fermentation characteristics and total tract diet digestibility were determined using the ruminally cannulated cows. On d 18 of each experimental period, $1,000 \mathrm{~mL}$ of ruminal contents were collected by manually taking $250 \mathrm{~mL}$ of ruminal contents from the cranial ventral, caudal ventral, central, and cranial dorsal rumen through the cannula at 0 (just before the morning feeding), 2, 4, and $6 \mathrm{~h}$ after feeding. Ruminal fluid samples were obtained by straining ruminal contents through 4 layers of cheesecloth. Ruminal fluid $\mathrm{pH}$ was immediately determined using a Model 265A portable pH meter (Orion Research Inc., Beverly, MA). A 5-mL sub-sample of strained ruminal fluid was mixed with chilled $25 \%$ meta-phosphoric acid $\left(\mathrm{H}_{2} \mathrm{PO}_{4}\right)$ and stored at $-20^{\circ} \mathrm{C}$ for later determination of VFA. Another $5-\mathrm{mL}$ sub-sample was mixed with $1 \% \mathrm{H}_{2} \mathrm{SO}_{4}$ and stored at $-20^{\circ} \mathrm{C}$ for later determination of ammonia- $\mathrm{N}\left(\mathrm{NH}_{3}-\mathrm{N}\right)$. At the end of the trial, frozen ruminal fluid sub-samples were thawed at room temperature and then centrifuged at $20,000 \times g$ for $20 \mathrm{~min}$. Ruminal VFA were separated and quantified by gas chromatography (Varian 3700; Varian Specialties Ltd., Brockville, Ontario, Canada) with a 15-m (0.53-mm i.d.) fused silica column (DBFFAP column; J and W Scientific, Folsom, CA). Ammonia content of ruminal samples was determined using the method described by Weatherburn (1967) modified to use a microtiter plate reader.

Total tract nutrient digestibility was determined by total collection of feces and urine between d 17 and 21 of each experimental period. Feces were collected into large steel trays that were positioned over the gutter behind each stall. Total daily fecal output for each cow was mixed thoroughly before a $2.5 \%$ sub-sample was taken and stored at $-20^{\circ} \mathrm{C}$. At the end of the trial, frozen fecal sub-samples were thawed, dried at $55^{\circ} \mathrm{C}$, and then 
ground through a 1-mm screen using a Christy-Norris mill (Christy and Norris Ltd.). Ground fecal samples were then composited per cow for each experimental period and analyzed for $\mathrm{OM}, \mathrm{CP}, \mathrm{EE}$, starch, $\mathrm{ADF}$, and NDF using the methods already described for pooled TMR and orts samples.

Total urine output was collected using indwelling Bardex Foley bladder catheters (26 Fr, 75-mL ribbed balloon, lubricious-coated; C. R. Bard Inc., Covington, GA). Bladder catheter insertion was conducted as described by Crutchfield (1968). Catheters were inserted at $0900 \mathrm{~h}$ on $\mathrm{d} 16$ and were then connected to urine collection tubing at $0900 \mathrm{~h}$ on $\mathrm{d} 17$. Urine was collected into 20-L Carboy polyethylene containers into which $150 \mathrm{~mL}$ of concentrated hydrochloric acid had been added to achieve urine $\mathrm{pH}$ of less than 3 . The acidification of urine was necessary to prevent microbial degradation and the loss of volatile $\mathrm{NH}_{3}-\mathrm{N}$. Daily urinary output was weighed, mixed thoroughly, and $5 \%$ of the output was drawn, pooled for each cow during each collection period, and stored at $-20^{\circ} \mathrm{C}$ until analyzed for total $\mathrm{N}$. Urine $\mathrm{N}$ was determined by the macroKjeldahl procedure (AOAC, 1990) using a Kjeltec 2400 auto-analyzer (FOSS Analytical, Hillerød, Denmark). In addition, a 2-mL aliquot of urine was diluted with $8 \mathrm{~mL}$ of distilled water and stored at $-20^{\circ} \mathrm{C}$ for later analysis. Diluted urine samples were pooled per cow according to daily urine output for each period and analyzed for allantoin by the colorimetric method described by Chen and Gomes (1992). Uric acid was determined in the same samples according to Fossati et al. (1980), using a commercial kit (Stanbio Uric acid Liquicolor; Stanbio Laboratory). Total purine derivative (PD; i.e., allantoin + uric acid) excretion per day was used to estimate microbial $\mathrm{N}$ yield as described by Chen and Gomes (1992), with the exception that a constant endogenous PD fraction of $56.86 \mathrm{mmol} / \mathrm{d}$ was used in the calculation (Gonzalez-Ronquillo et al., 2003). Nitrogen retained was calculated as intake $\mathrm{N}-$ fecal $\mathrm{N}$ - urinary $\mathrm{N}-$ milk $\mathrm{N}$. Milk $\mathrm{N}$ was determined as milk $\mathrm{CP} \div 6.38$.

\section{Statistical Analysis}

Data on DMI, milk yield and composition, plasma urea nitrogen, and glucose were analyzed as a replicated $4 \times 4$ Latin square using the Proc Mixed procedure of SAS (SAS Institute, 2004) using the following model: $\mathrm{Y}_{\mathrm{ijkl}}=\mu+\mathrm{S}_{\mathrm{i}}+\mathrm{P}_{\mathrm{j}(\mathrm{i})}+\mathrm{C}_{\mathrm{k}(\mathrm{i})}+\mathrm{T}_{1}+\varepsilon_{\mathrm{ijk} k}$, where $\mathrm{Y}_{\mathrm{ijkl}}$ is the dependent variable, $\mu$ is the overall mean, $S_{i}$ is the fixed effect of square $i, P_{j(i)}$ is the fixed effect of period $j$ (within square $\mathrm{i}), \mathrm{C}_{\mathrm{k}(\mathrm{i})}$ is the random effect of cow $\mathrm{k}$ (within square i), $\mathrm{T}_{1}$ is the fixed effect of treatment $\mathrm{l}$, and $\varepsilon_{\mathrm{ijkl}}$ is the random residual error. For urinary PD fractions and $\mathrm{N}$ balance data, the following model was used: $\mathrm{Y}_{\mathrm{ijkl}}=$
$\mu+P_{i}+C_{j}+T_{k}+\varepsilon_{i j k}$, where $Y_{i j k}$ is the dependent variable, $\mu$ is the overall mean, $P_{i}$ is the fixed effect of period i, $C_{j}$ is the random effect of cow $j, T_{k}$ is the fixed effect of treatment $\mathrm{k}$, and $\varepsilon_{\mathrm{ijk}}$ is the random residual error. Measurements of ruminal $\mathrm{pH}$, ruminal VFA, and $\mathrm{NH}_{3}-\mathrm{N}$ concentrations were analyzed as repeated measures using PROC MIXED procedure (SAS Institute, 2004). The statistical model used included period, treatment, time, and treatment $\times$ time interaction as fixed effects, and cow as a random effect. The subject of the repeated measurement was defined as cow (period $x$ treatment). The Kenward-Roger option was used to estimate denominator degrees of freedom. The 9 covariance structures that were tested were autoregressive 1 (AR [1]), compound symmetry (CS), heterogeneous autoregressive (ARH [1]); unstructured (UN), variance components (VC), Toeplitz (Toep), heterogeneous compound symmetry (CSH), heterogeneous Toeplitz (Toeph), and simple. The covariance structure with the lowest (closest to zero) Akaike's information criterion values was selected (Littell et al., 1996). Least square means were separated using Bonferroni's procedure in SAS (2004). Treatment effects were declared significant at $P \leq 0.05$, and tendencies from $P>0.05$ to $\leq 0.10$. The $P$-values that are indicated in Tables 2, 4, 5, and 6 refer to overall diet effects. Where diet effects were or tended to be significant, the $P$-values that are indicated in the Results and Discussion refer to mean separation.

\section{RESULTS AND DISCUSSION}

\section{Diet Characteristics}

The ingredient composition and chemical analysis of experimental TMR are presented in Table 1. Across diets, the DM, CP, ADF, NDF, and starch contents were (mean $\pm \mathrm{SE}$ ) $54.6 \pm 0.4,17.4 \pm 0.3,26.7 \pm 0.6,33.6 \pm$ 1.4 , and $19.7 \pm 3.3 \%$ (DM basis), respectively (Table 1 ). The starch content of the oats-based diet was numerically lower than that of the barley-, corn-, and wheatbased diets (Table 1), which is a reflection of differences in starch contents of the original cereal grains. It is noteworthy that the lower starch content of the oatsbased diet did not compromise production performance when compared with the diets with numerically higher starch contents. Average dietary ADF and NDF contents were higher than or in the high end of NRC (2001) minimum recommendations of 17 to $21 \%$ and 25 to $33 \%$, respectively, for the maintenance of proper ruminal function. This was related to greater than anticipated $\mathrm{ADF}$ and NDF concentrations of the barley silage used in this study. Diets formulated to contain NDF above the minimum NRC (2001) recommendations can limit DM intake; however, in the present study, average DM intake was $25.4 \mathrm{~kg} / \mathrm{d}$, or approximately $3.8 \%$ of mean 
Table 2. Dry matter intake, milk yield and milk composition, and plasma metabolites of dairy cows fed diets containing barley, corn, wheat, and oats as the main source of carbohydrate ${ }^{1}$

\begin{tabular}{|c|c|c|c|c|c|c|}
\hline \multirow[b]{2}{*}{ Item } & \multicolumn{4}{|c|}{ Source of carbohydrate in the diet } & \multirow[b]{2}{*}{ SEM } & \multirow[b]{2}{*}{$P$ value } \\
\hline & Barley & Corn & Wheat & Oats & & \\
\hline DMI, kg/d & 26.2 & 26.0 & 24.0 & 25.2 & 0.59 & 0.07 \\
\hline Milk yield, kg/d & 40.2 & 38.9 & 36.8 & 38.4 & 0.80 & 0.06 \\
\hline $3.5 \% \mathrm{FCM}^{3}{ }^{3} \mathrm{~kg} / \mathrm{d}$ & $37.9^{\mathrm{a}}$ & $38.4^{\mathrm{a}}$ & $34.8^{\mathrm{b}}$ & $37.0^{\mathrm{ab}}$ & 0.72 & 0.02 \\
\hline Fat, \% & $3.20^{\mathrm{b}}$ & $3.45^{\mathrm{a}}$ & $3.20^{\mathrm{b}}$ & $3.34^{\mathrm{ab}}$ & 0.05 & 0.02 \\
\hline Fat yield, kg/d & $1.26^{\mathrm{ab}}$ & $1.33^{\mathrm{a}}$ & $1.16^{\mathrm{b}}$ & $1.26^{\mathrm{ab}}$ & 0.03 & $<0.01$ \\
\hline Protein, \% & $3.00^{\mathrm{ab}}$ & $3.07^{\mathrm{a}}$ & $3.00^{\mathrm{ab}}$ & $2.96^{\mathrm{b}}$ & 0.03 & 0.02 \\
\hline Protein yield, kg/d & $1.20^{\mathrm{a}}$ & $1.18^{\mathrm{ab}}$ & $1.10^{\mathrm{b}}$ & $1.12^{\mathrm{ab}}$ & 0.02 & 0.02 \\
\hline Lactose, \% & 4.33 & 4.39 & 4.35 & 4.34 & 0.02 & 0.10 \\
\hline Plasma glucose, $\mathrm{mg} / \mathrm{dL}$ & 45.4 & 46.9 & 47.5 & 45.7 & 0.78 & 0.25 \\
\hline Plasma urea-N, mg/dL & 18.1 & 16.9 & 17.5 & 19.0 & 0.57 & 0.10 \\
\hline
\end{tabular}

${ }^{\mathrm{a}, \mathrm{b}}$ Means within a row with different superscripts differ $(P<0.05)$. Means were separated using Bonferroni's procedure (SAS Institute, 2004).

${ }^{1}$ Data were obtained from all 8 cows used in the 2 Latin squares.

${ }^{2} P$-values indicate overall diet effects.

${ }^{3}$ Calculated as $(0.434 \times \mathrm{kg}$ of milk $)+(16.216 \times \mathrm{kg}$ of milk fat $)$.

$\mathrm{BW}$, and this falls within the expected range for dairy cows producing $>35 \mathrm{~kg} / \mathrm{d}$ of milk (NRC, 2001). Averaged across treatments, dietary fat was $5.5 \pm 0.2 \%$ on a DM basis, which falls within the desired range of 5 to $6 \%$ total dietary fat. Fat levels exceeding 6 to $7 \%$ reduce fiber digestion and, consequently, lower DM intake in dairy cows (NRC, 2001); hence, it was desired to maintain total dietary fat below $6 \%$ of DM. Percentages (asfed basis) of the forage mixture retained on the 19.0-, $8.0-$, and 1.18-mm screens, and the bottom pan of the PSPS were $3.2,37.5,48.2$, and $11.1 \%$, respectively, and particle size distribution for the forage mixture was numerically similar across diets.

\section{DMI, Milk Yield and Milk Composition, and Plasma Metabolites}

Dry matter intake tended to be lower $(P=0.10)$ for cows fed the wheat-based TMR than cows on the barleybased TMR. Cows fed barley-, corn-, or oats-based TMR consumed $2.2,2.0$, and $1.2 \mathrm{~kg} / \mathrm{d}$ of DM more, respectively, compared with those fed the wheat-based TMR (Table 2). Actual milk yield also tended to be lower $(P=$ 0.06) in cows fed the wheat-based diet compared with those fed the barley-based TMR. On average, cows fed barley-, corn-, and oats-based TMR produced 3.4, 2.1, and $1.6 \mathrm{~kg} / \mathrm{d}$ more milk, respectively, compared with those fed the wheat-based TMR (Table 2). According to dietary $\mathrm{NE}_{\mathrm{L}}$ estimates from the NRC (2001), the extra DM consumed by cows fed the barley-, corn-, or oatsbased TMR above that of cows fed the wheat-based TMR corresponds to an additional intake of between 1.9 and $3.5 \mathrm{Mcal} / \mathrm{d}$ of $\mathrm{NE}_{\mathrm{L}}$, which would explain the greater milk yield. Assuming caloric values of 9.3, 5.9, and $4.0 \mathrm{kcal} / \mathrm{g}$ of milk fat, protein, and lactose, respec- tively (Arieli et al., 2001), this extra $\mathrm{NE}_{\mathrm{L}}$ intake corresponds to an additional 5.5, 4.7, and $2.9 \mathrm{~kg} / \mathrm{d}$ of milk (assuming similar milk contents of fat, protein, and lactose as indicated in Table 2) in cows fed barley-, corn-, and oats-based TMR, respectively. The observed differences in milk production among dietary treatments did not achieve the levels predicted from estimated energy intakes; however, the pattern of difference appears to be similar to that predicted. Standardizing milk to $3.5 \%$ FCM yield accentuated the differences in yield between wheat- and corn-based TMR $(P=0.02)$ and wheat- and barley-based TMR $(P=$ 0.05 ; Table 2).

A preponderance of comparative studies conducted under North American conditions have investigated production responses in trials comparing fewer cereal grain types, most commonly corn and barley. Additionally, the few studies in the literature showed variable production responses. Tommervik and Waldern (1969) reported similar milk yields across dietary treatments when diets containing wheat, barley, oats, or corn were fed. Similarly, grazing cows supplemented with $3 \mathrm{~kg} / \mathrm{d}$ of wheat, barley, oats, or corn yielded similar amounts of milk (Jeffery et al., 1976). Moran (1986) reported higher FCM yields in cows fed oats-based diets compared with those fed wheat- or barley-based diets, although DM intakes were similar for all diets. Grings et al. (1992) and Khorasani et al. (1994) did not observe any dietary effects on milk yield with diets containing corn or barley as the principal source of starch. In contrast, others (McCarthy et al., 1989; Casper et al., 1999) reported stimulatory effects on milk yield in cows fed corn-based compared with barley-based diets. Among other things, responses of lactating cows to different cereal grains depend on the level of dietary inclusion, 
the basal ration, physical processing of the cereal grains, the composition of a given batch of cereal grain, and the level of dietary intake (Moran, 1986; Khorasani et al., 2001); therefore, direct comparisons among studies are often not possible.

In the current study, feeding the corn-based TMR resulted in greater fat content compared with feeding the barley-based $(P=0.05)$ or wheat-based $(P=0.04)$ TMR, whereas fat yield was only higher $(P<0.01)$ in cows fed corn- compared with wheat-based TMR diets (Table 2). In contrast, Tommervik and Waldern (1969) reported similar milk fat contents and yields in cows fed wheat, barley, oats, or corn as the principal energy concentrates. Similarly, Moran (1986) reported no differences in milk fat content in cows fed wheat, barley, or oats; however, milk fat yield was higher in cows fed oats compared with those fed barley or wheat. Higher fat content in milk from cows fed corn compared with those fed barley diets have been reported previously (DePeters and Taylor, 1985; Weiss et al., 1989; Khorasani et al., 2001). Dietary differences on milk compositional quality are generally reflective of differences in patterns of ruminal fermentation (Moran, 1986) and in the site and extent of cereal grain digestion (Khorasani et al., 2001). Previous studies have reported milk fat depression with decreased ruminal acetate to propionate ratios (Griinari et al., 1998; Onetti et al., 2002); however, the acetate to propionate ratios in the present study did not differ across dietary treatments. Milk protein content was higher $(P=0.01)$ in cows fed cornbased TMR compared with those fed oats-based TMR, whereas protein yield tended to be lower in cows fed wheat-based TMR compared with those fed barleybased TMR $(P=0.05)$ or corn-based TMR $(P=0.10)$. This was partly due to the tendency for higher milk yield in cows fed the barley- and corn-based TMR compared with cows fed the wheat-based TMR. Milk lactose content did not differ $(P=0.10)$ among dietary treatments (Table 2).

Plasma concentrations of glucose did not respond to dietary treatment (Table 2). Under most dietary conditions, intestinal absorption of glucose in dairy cows is limited due to the extensive ruminal fermentation of dietary starch; thus, plasma glucose largely arises from hepatic gluconeogenesis using ruminally derived propionate as the principal precursor (Huntington, 1997). In the present study, ruminal propionate concentrations were not altered by dietary treatment, so this observation might partly explain the lack of dietary differences in plasma glucose. Plasma urea-N tended to be greater in cows fed the oats-based TMR compared with those fed the barley-, corn-, or wheat-based TMR (Table 2; $P=$ $0.10)$. In dairy cows, PUN largely arises from ruminal catabolism of dietary protein, with the resultant rumi- nal $\mathrm{NH}_{3}-\mathrm{N}$ that is not captured for microbial protein synthesis being absorbed into portal blood and converted to urea in the liver (NRC, 2001). Although numerous factors determine the efficiency of capture of ruminal $\mathrm{NH}_{3}-\mathrm{N}$ for microbial growth, total starch and ruminally degradable starch (RDS) intake appear to be the major factors (Theurer et al., 1999). In the present study, cows fed the oats-based TMR consumed 1.2 to $1.8 \mathrm{~kg} / \mathrm{d}$ less starch compared with those fed the barley, corn-, and wheat-based TMR. The lower starch intake in cows fed the oats-based diet could potentially limit the ability of ruminal microorganisms to utilize ruminal $\mathrm{NH}_{3}-\mathrm{N}$, thus resulting in higher rates of ureagenesis. However, it is noteworthy that dietary differences in ruminal concentrations of $\mathrm{NH}_{3}-\mathrm{N}$ were absent. Others (Casper et al., 1999) found no effect of barley- or cornbased diets on PUN.

\section{Ruminal Fermentation Characteristics and Apparent Total Tract Diet Digestibility}

Ruminal $\mathrm{pH}$ was unaffected by dietary treatment (Table 3). Cereal grains differ in their starch contents, and rates and extents of ruminal starch fermentation (Huntington, 1997), with oats and wheat exhibiting a faster and more extensive ruminal starch degradation compared with barley or corn. Therefore, dietary differences in ruminal $\mathrm{pH}$ were expected and the reasons for a lack of effect on ruminal $\mathrm{pH}$ are unclear. Cows fed the oats-based TMR consumed 1.2 to $1.8 \mathrm{~kg} / \mathrm{d}$ less starch compared with those fed the barley-, corn-, and wheatbased TMR, so it is plausible that the lack of dietary differences in ruminal $\mathrm{pH}$ could be attributable to the lower starch intakes in cows fed oats-based TMR. Additionally, it is possible that a more intensive sampling schedule during a 24-h feeding cycle or the use of continuous ruminal $\mathrm{pH}$ measurements may have been able to give a definitive indication of changes in $\mathrm{pH}$. Additionally, high NDF concentrations across all dietary treatments may have resulted in high rumen buffering. Dietary NDF concentration is inversely related to ruminal $\mathrm{pH}$ because higher dietary NDF promotes less ruminal acid production and stimulates chewing and saliva production (NRC, 2001), which could have resulted in smaller, undetectable differences in ruminal $\mathrm{pH}$ across dietary treatments. In comparative studies with diets containing barley, wheat, or oats as the principal starch sources, ruminal pH was not affected by the choice of cereal grain (Moran, 1986), and this is similar to findings of the present study. Ruminal $\mathrm{pH}$ ranged from 5.8 to 6.9 and, as expected, declined with time postfeeding in a similar pattern across dietary treatments.

Ruminal $\mathrm{NH}_{3}-\mathrm{N}$ concentration was unaffected by dietary treatment (Table 3). Moran (1986) fed dairy cows 
Table 3. Ruminal fermentation characteristics of dairy cows fed diets containing barley, corn, wheat, and oats as the main source of carbohydrate ${ }^{1}$

\begin{tabular}{|c|c|c|c|c|c|c|c|c|}
\hline \multirow[b]{2}{*}{ Item } & \multicolumn{4}{|c|}{ Source of carbohydrate in the diet } & \multirow[b]{2}{*}{ SEM } & \multicolumn{3}{|c|}{$P$-value } \\
\hline & Barley & Corn & Wheat & Oats & & Cereal & Time & Cereal $\times$ time \\
\hline Ruminal pH & 6.26 & 6.18 & 6.11 & 6.20 & 0.11 & 0.84 & $<0.01$ & 0.11 \\
\hline $\begin{array}{l}\text { Ruminal } \mathrm{NH}_{3}-\mathrm{N}, \mathrm{mg} / \mathrm{dL} \\
\text { VFA concentration, } \mathrm{m} M\end{array}$ & 15.6 & 16.0 & 15.6 & 14.5 & 1.37 & 0.86 & $<0.01$ & 0.66 \\
\hline Acetate & 68.6 & 71.4 & 72.6 & 67.9 & 3.04 & 0.67 & $<0.01$ & 0.11 \\
\hline Propionate & 22.1 & 22.5 & 27.6 & 22.4 & 2.74 & 0.45 & $<0.01$ & 0.28 \\
\hline Butyrate & 13.8 & 14.8 & 13.2 & 13.2 & 1.13 & 0.72 & $<0.01$ & 0.92 \\
\hline Isobutyrate & 1.22 & 1.29 & 1.35 & 1.11 & 0.08 & 0.15 & $<0.01$ & 0.89 \\
\hline Valerate & 1.92 & 1.85 & 2.44 & 1.71 & 0.19 & 0.05 & $<0.01$ & 0.96 \\
\hline Isovalerate & 1.98 & 1.97 & 2.01 & 1.74 & 0.23 & 0.84 & $<0.01$ & 0.66 \\
\hline Total VFA & 102.6 & 111.0 & 124.2 & 99.6 & 6.46 & 0.59 & $<0.01$ & 0.24 \\
\hline Acetate:Propionate ratio & 3.21 & 3.24 & 2.83 & 3.15 & 0.28 & 0.58 & $<0.01$ & 0.85 \\
\hline
\end{tabular}

${ }^{1}$ Values are means across sampling times of $0,2,4$, and $6 \mathrm{~h}$ after a.m. feeding.

complete diets containing barley, wheat, or oats as the principal starch sources and did not observe dietary effects on ruminal $\mathrm{NH}_{3}-\mathrm{N}$ concentration. Across dietary treatments, ruminal $\mathrm{NH}_{3}-\mathrm{N}$ concentrations ranged from 9 to $24 \mathrm{mg} / \mathrm{dL}$ and changes in ruminal $\mathrm{NH}_{3}-\mathrm{N}$ concentrations with time postfeeding were similar across diets. Mean ruminal $\mathrm{NH}_{3}-\mathrm{N}$ concentrations were $>5 \mathrm{mg} / \mathrm{dL}$ at all sampling times postfeeding, which has been suggested to be adequate for maximum microbial protein synthesis (Satter and Slyter, 1974).

Individual concentrations for most ruminal VFA were not affected by dietary treatment but the concentration of valerate tended to be lower $(P=0.07)$ for cows fed oats-based TMR compared with those fed wheat-based TMR (Table 3). Total VFA concentrations were also unaffected by dietary treatment (Table 3). Consequently, the acetate to propionate ratio was also not affected by dietary treatment. As the rate of ruminal starch degradation is different among cereal grains, it is reasonable to expect differences in ruminal VFA concentrations when diets containing different cereal grains are fed. In other comparative studies with corn and barley, differences in ruminal patterns of VFA were small or absent (DePeters and Taylor, 1985; Weiss et al., 1989). Because ruminal fermentation characteristics were measured just before feeding and at 2-h intervals for $6 \mathrm{~h}$ after morning feeding, a time $\times$ treatment interaction for ruminal $\mathrm{pH}$, ruminal ammonia, and VFA would be indicative of differences in fermentation patterns; however, there was no treatment $\times$ time interaction for any of the ruminal fermentation characteristics measured, which indicates that fermentation patterns were essentially similar across diets (Table 3 ).

Total tract digestibility of DM, OM, and NDF were not affected by dietary source of carbohydrate (Table 4). Total tract $\mathrm{ADF}$ digestibility tended to be lower $(P=$ 0.10 ) in cows fed the wheat-based TMR compared with those fed the corn-based TMR (Table 4). Compared with cows fed the oats-based TMR, apparent total tract starch digestibility was lower in cows fed the corn-based $(P=0.01)$ or wheat-based $(P<0.01)$ TMR. Apparent total tract starch digestibility also tended to be lower $(P=0.08)$ in cows fed the barley-based TMR than in those fed the oats-based TMR (Table 4). Across dietary treatments, apparent total tract starch digestibility was $>90 \%$. In dairy cows, the major site of cereal grain starch digestion is the rumen and, with oats exhibiting a faster and more extensive ruminal starch degradation compared with wheat, barley, and corn (Huntington, 1997), it was expected that total tract starch digestibility would be greater in cows fed the oats-based TMR. Moran (1986) also reported a higher total tract starch digestibility in dairy cows fed oats compared with those fed wheat or barley.

Compared with cows fed the oats-based TMR, apparent total tract $\mathrm{CP}$ digestibility was lower in cows fed the corn-based $(P=0.02)$ and wheat-based $(P=0.01)$ TMR (Table 4). This response might be related to the relative extents of ruminal starch degradation of the cereal grains. Higher levels of undigested starch reaching the hindgut in cows fed the corn- and wheat-based diets compared with those fed the oats-based diet might have promoted more bacterial protein synthesis in the hindgut (Orskov et al., 1970). Because there is no mechanism for hindgut enzymatic digestion of the resultant bacterial protein, it is voided in the feces, thus reducing the total tract CP digestibility (Orskov et al., 1970). In addition, differences in apparent total tract CP digestibility may be due to differences in the digestibility of the protein of the cereal grains (Herrera-Saldana et al., 1990; McAllister et al., 1993).

\section{Nitrogen Balance and Microbial N Flow}

Nitrogen intake was similar across diets, in part because DMI (i.e., for cows used in the metabolism trial; 
Table 4. Total tract nutrient digestibility of dairy cows fed diets containing barley, corn, wheat, and oats as the main source of carbohydrate ${ }^{1}$

\begin{tabular}{|c|c|c|c|c|c|c|}
\hline \multirow[b]{2}{*}{ Item } & \multicolumn{4}{|c|}{ Source of carbohydrate in the diet } & \multirow[b]{2}{*}{ SEM } & \multirow[b]{2}{*}{$P$-value ${ }^{2}$} \\
\hline & Barley & Corn & Wheat & Oats & & \\
\hline DMI, kg/d & 25.8 & 26.3 & 24.0 & 24.8 & 1.51 & 0.72 \\
\hline \multicolumn{7}{|l|}{ Digestibility, \% } \\
\hline DM & 63.7 & 63.1 & 59.5 & 62.1 & 1.39 & 0.22 \\
\hline $\mathrm{OM}$ & 65.7 & 64.6 & 61.2 & 63.9 & 1.30 & 0.16 \\
\hline $\mathrm{CP}$ & $66.3^{\mathrm{ab}}$ & $63.2^{\mathrm{b}}$ & $62.9^{\mathrm{b}}$ & $70.1^{\mathrm{a}}$ & 1.21 & $<0.01$ \\
\hline $\mathrm{ADF}$ & 45.2 & 49.2 & 37.7 & 39.3 & 2.72 & 0.05 \\
\hline $\mathrm{NDF}$ & 41.1 & 43.4 & 30.2 & 38.5 & 3.55 & 0.11 \\
\hline Starch & $92.6^{\mathrm{ab}}$ & $91.3^{\mathrm{b}}$ & $90.9^{\mathrm{b}}$ & $95.8^{\mathrm{a}}$ & 0.72 & $<0.01$ \\
\hline
\end{tabular}

${ }^{\mathrm{a}, \mathrm{b}}$ Means within a row with different superscripts $\operatorname{differ}(P<0.05)$. Means were separated using Bonferroni's procedure (SAS Institute, 2004).

${ }^{1}$ Measurements were done only in the 4 ruminally cannulated cows.

${ }^{2} P$-values indicate overall diet effects.

see Table 4) was not affected by treatment and also because the diets were formulated to be isonitrogenous (Table 5). However, as a proportion of $\mathrm{N}$ intake, fecal $\mathrm{N}$ excretion was greatest in cows fed the wheat- and corn-based diets, intermediate in those fed the barleybased diet, and least for those fed the oats-based diet (Table 5). Urinary $\mathrm{N}$ excretion, as a proportion of $\mathrm{N}$ intake, tended to be lesser $(P=0.09)$ in cows fed cornbased diets compared with those fed wheat-based diets. As a proportion of urinary $\mathrm{N}$, urea-N was higher $(P<$ 0.01 ) in cows fed corn- and oats-based diets. Nitrogen that was used for productive purposes ( $\mathrm{N}$ secreted in milk plus $\mathrm{N}$ apparently retained by the cow) tended to be lesser $(P=0.06)$ in cows fed the wheat-based diet compared with cows fed barley-, corn-, or oats-based diets, reflecting the higher total $\mathrm{N}$ excretion (expressed as a \% of $\mathrm{N}$ intake) in cows fed the wheat-based diet (Table 5). Additionally, the wheat-based diet contained less canola meal and soybean meal compared with the other diets (Table 1), and this could potentially limit metabolizable protein flow to the small intestine in cows fed the wheat-based diet. When urinary $\mathrm{N}$ excretion was expressed as a proportion of $\mathrm{N}$ intake (Table 5), cereal grains were ranked as wheat $>$ oats $>$ barley $>$ corn, which is the reverse ranking in terms of predicted ruminal starch digestibility (Huntington, 1997).

Total purine excretion was higher $(P=0.04)$ in cows fed the barley-based diets compared with those fed the oats-based diets, and intermediate in cows fed the cornand wheat-based TMR (Table 6). Consequently, the calculated intestinal flow of microbial $\mathrm{N}$ was also higher $(P=0.04)$ in cows fed the barley-based TMR compared

Table 5. Nitrogen balance in dairy cows fed diets containing barley, corn, wheat, and oats as the main source of carbohydrate

\begin{tabular}{|c|c|c|c|c|c|c|}
\hline \multirow[b]{2}{*}{ Item } & \multicolumn{4}{|c|}{ Source of carbohydrate in the diet } & \multirow[b]{2}{*}{ SEM } & \multirow[b]{2}{*}{$P$-value ${ }^{1}$} \\
\hline & Barley & Corn & Wheat & Oats & & \\
\hline $\mathrm{N}$ intake, g/d & 727 & 723 & 669 & 686 & 38.4 & 0.35 \\
\hline \multicolumn{7}{|l|}{ Fecal N excretion } \\
\hline $\mathrm{g} / \mathrm{d}$ & 246 & 266 & 251 & 207 & 14.8 & 0.09 \\
\hline$\%$ of $\mathrm{N}$ intake & $33.9^{\mathrm{ab}}$ & $36.8^{\mathrm{a}}$ & $37.4^{\mathrm{a}}$ & $30.3^{\mathrm{b}}$ & 1.00 & $<0.01$ \\
\hline \multicolumn{7}{|l|}{ Urinary $\mathrm{N}$ excretion } \\
\hline $\mathrm{g} / \mathrm{d}$ & 267 & 236 & 255 & 265 & 15.0 & 0.47 \\
\hline$\%$ of $\mathrm{N}$ intake & 36.8 & 32.8 & 40.0 & 38.2 & 1.75 & 0.10 \\
\hline$\%$ of total $\mathrm{N}$ excretion & $52.0^{\mathrm{ab}}$ & $46.8^{\mathrm{b}}$ & $50.5^{\mathrm{ab}}$ & $56.2^{\mathrm{a}}$ & 1.27 & 0.01 \\
\hline Urea-N, g/d & 219 & 223 & 210 & 238 & 14.7 & 0.56 \\
\hline Urea-N, \% of urinary $\mathrm{N}$ & $82^{\mathrm{b}}$ & $94^{\mathrm{a}}$ & $82^{\mathrm{b}}$ & $90^{\mathrm{ab}}$ & 2.25 & $<0.01$ \\
\hline Total N excretion, g/d & 513 & 501 & 506 & 472 & 27.8 & 0.74 \\
\hline $\mathrm{N}$ retention, $\mathrm{g} / \mathrm{d}$ & 35 & 43 & -5 & 48 & 16.2 & 0.10 \\
\hline Milk N, g/d & 179 & 178 & 168 & 166 & 11.0 & 0.30 \\
\hline Productive $\mathrm{N},{ }^{2} \mathrm{~g} / \mathrm{d}$ & 214 & 221 & 163 & 214 & 22.0 & 0.06 \\
\hline
\end{tabular}


Table 6. Urine output, urinary purine derivative excretion, and microbial $\mathrm{N}$ supply in dairy cows fed diets containing barley, corn, wheat, and oats as the main source of carbohydrate

\begin{tabular}{|c|c|c|c|c|c|c|}
\hline \multirow[b]{2}{*}{ Item } & \multicolumn{4}{|c|}{ Source of carbohydrate in the diet } & \multirow[b]{2}{*}{ SEM } & \multirow[b]{2}{*}{$P$-value } \\
\hline & Barley & Corn & Wheat & Oats & & \\
\hline Urine output, kg/d & $29.0^{\mathrm{ab}}$ & $30.5^{\mathrm{a}}$ & $27.6^{\mathrm{ab}}$ & $26.4^{\mathrm{b}}$ & 1.93 & 0.03 \\
\hline Allantoin, mmol/d & 378 & 369 & 344 & 325 & 10.3 & 0.04 \\
\hline Uric acid, $\mathrm{mmol} / \mathrm{d}$ & 57 & 58 & 53 & 53 & 6.21 & 0.80 \\
\hline Total purine derivatives, $\mathrm{mmol} / \mathrm{d}$ & $436^{\mathrm{a}}$ & $427^{\mathrm{ab}}$ & $397^{\mathrm{ab}}$ & $379^{\mathrm{b}}$ & 14.2 & 0.02 \\
\hline Microbial N supply, ${ }^{2} \mathrm{~g} / \mathrm{d}$ & $324^{\mathrm{a}}$ & $316^{\mathrm{ab}}$ & $291^{\mathrm{ab}}$ & $275^{\mathrm{b}}$ & 8.60 & 0.02 \\
\hline
\end{tabular}

with those fed the oats-based TMR (Table 6). Based on DMI and dietary starch contents, cows fed the oatsbased TMR consumed 1.2 to $1.8 \mathrm{~kg} / \mathrm{d}$ less starch compared with those fed the barley-, corn-, and wheat-based TMR. A lower total starch intake in cows fed the oatsbased TMR could partly explain the lower total PD excretion and, consequently, the lower intestinal flow of microbial $\mathrm{N}$ when compared with cows fed the barleybased TMR. Data summarized by Theurer et al. (1999) showed that a decrease in total starch or RDS intake was associated with a decrease in microbial $\mathrm{N}$ flow in dairy cows. Considering that there were only numerical differences in DMI, the wheat-based diet was expected to result in improved microbial $\mathrm{N}$ flow to the duodenum due to a higher RDS intake (Firkins et al., 2001), when compared with the barley- or corn-based diets. However, dietary RDP content in the wheat-based TMR may have differed from that of the other diets due to a lower content of canola meal and soybean meal. Lower levels of these ingredients in the wheat-based TMR were necessary to achieve isonitrogenous experimental diets with all 4 cereal grains. The effect of RDS in the diet has not always yielded consistent results in previous studies in the literature. For example, a review of the literature by Cabrita et al. (2006) shows that more RDS in the diet increased microbial $\mathrm{N}$ supply in 2 studies and had no effect in 5 studies. In the present study, inclusion of the less degradable starch sources (barley and corn, compared with wheat) in the diet increased microbial N supply.

\section{CONCLUSIONS}

This study demonstrates that feeding barley-, corn-, or oats-based TMR resulted in similar levels of intake but that feeding wheat-based TMR tended to depress DMI. Consequently fat-corrected milk yield decreased in cows fed wheat-based diets. Feeding barley- or wheat-based TMR depressed milk fat content, but milk fat yield was only depressed with the wheat-based
TMR. However, milk fat yield was not adversely affected in cows on the barley-based TMR because the marginally higher milk yields achieved with this diet compensated for the milk fat depression. In spite of likely differences in ruminally degradable starch contents of these diets, ruminal fermentation characteristics did not differ within the first $6 \mathrm{~h}$ after morning feeding. Nitrogen balance was similar across diets. The marginally superior production performance with barley- and corn-based TMR may have been due to a higher nutrient intake in cows on these diets compared with those on wheat-based TMR. Urine excretion of PD indicated higher microbial protein availability at the small intestine in cows fed barley- and corn-based diets compared with those fed oats- and wheat-based diets. The data from this study further demonstrate that, even though we perceive that the kinetics of rumen degradation of rations are a function of the nature and constituents of the feeds, using this information to manipulate rumen microbial protein synthesis does not always yield the expected response.

\section{ACKNOWLEDGMENTS}

The authors would like to thank Marlene Fehr, Sujeema Abeysekara, and the staff of the Greenbrae Dairy Research Centre (University of Saskatchewan, SK, Canada) for their excellent technical assistance. Partial funding was contributed by the Saskatchewan Department of Agriculture, Food and Rural Revitalization.

\section{REFERENCES}

AOAC. 1990. Official Methods of Analysis. Vol. 1. 15th ed. Assoc. Off. Anal. Chem., Arlington, VA.

Arieli, A., S. Abramson, S. J. Mabjeesh, S. Zamwel, and I. Bruckental. 2001. Effect of site and source of energy supplementation on milk yield in dairy cows. J. Dairy Sci. 84:462-470.

Cabrita, A. R. J., R. J. Dewhurst, J. M. F. Abreu, and A. J. M. Fonseca. 2006. Evaluation of the effects of synchronising the availability of $\mathrm{N}$ and energy on rumen function and production responses of dairy cows-A review. Anim. Res. 55:1-24. 
Casper, D. P., H. A. Maiga, M. J. Brouk, and D. J. Schingoethe. 1999. Synchronization of carbohydrate and protein sources on fermentation and passage rate in dairy cows. J. Dairy Sci. 82:1779-1790.

Chen, X. B., and M. J. Gomes. 1992. Estimation of microbial protein supply to sheep and cattle based on urinary excretion of purine derivatives- and overview of the technical details. Int. Feed Resources Unit, Rowett Research Institute. Aberdeen, UK

Crutchfield, W. O. 1968. A technique for placement of an in-dwelling catheter in the cow. Vet. Med. Small Anim. Clin. 63:1141-1144.

DePeters, E. J., and S. J. Taylor. 1985. Effects of feeding corn or barley on composition of milk and diet digestibility. J. Dairy Sci. 68:2027-2032.

Firkins, J. L., M. L. Eastridge, N. R. St-Pierre, and S. M. Noftger. 2001. Effects of grain variability and processing on starch utilization by lactating dairy cattle. J. Anim. Sci. 79 (E. Suppl.):E218-E238.

Fossati, P., L. Prencipe, and G. Berti. 1980. Use of 3,5-dichloro-2hydroxybenzenesulfonic acid/4-aminophenazone chromogenic system in direct enzymic assay of uric acid in serum and urine. Clin. Chem. 26:227-231.

Gonzalez-Ronquillo, M., J. Balcells, J. A. Guada, and F. Vicente. 2003. Purine derivative excretion in dairy cows: Endogenous excretion and the effect of exogenous nucleic acid supply. J. Dairy Sci. 86:1282-1291.

Griinari, J. M., D. A. Dwyer, M. A. McGuire, D. E. Bauman, D. L. Palmquist, and K. V. Nurmela. 1998. Trans-octadecenoic acids and milk fat depression in lactating dairy cows. J. Dairy Sci. 81:1251-1261

Grings, E. E., R. E. Roffler, and D. P. Deitelhoff. 1992. Evaluation of corn and barley as energy sources for cows in early lactation fed alfalfa-based diets. J. Dairy Sci. 75:193-200.

Hall, M. B. 2004. Short communication: Effect of carbohydrate fermentation rate on estimates of mass fermented and milk response. J. Dairy Sci. 87:1455-1456.

Heinrichs, J. 1996. Pages 1-9 in Evaluating Particle Size of Forages and TMRs using the Penn State Particle Size Separator. Pennsylvania State University, State College.

Herrera-Saldana, R., J. T. Huber, and M. H. Poore. 1990. Dry matter, crude protein and starch degradability of five cereal grains. J. Dairy Sci. 73:2386-2393.

Hoover, W. H., and S. R. Stokes. 1991. Balancing carbohydrate and protein for optimum rumen microbial yield. J. Dairy Sci. 74:3630-3644

Huntington, G. B. 1997. Starch utilization by ruminants: From basics to the bunk. J. Anim. Sci. 75:852-867.

Jeffery, H., R. J. Buesnel, and G. H. O’Neill. 1976. Short-term studies on the response of grazing dairy cows to dietary supplementation. Aust. J. Exp. Agric. Anim. Husb. 16:445-451.

Khorasani, G. R., G. de Boer, B. Robinson, and J. J. Kennelly. 1994. Influence of dietary protein and starch on production and metabolic responses of dairy cows. J. Dairy Sci. 77:813-824.

Khorasani, G. R., E. K. Okine, and J. J. Kennelly. 2001. Effects of substituting barley grain with corn on ruminal fermentation characteristics, milk yield, and milk composition of Holstein cows. J. Dairy Sci. 84:2760-2769.
Koenig, K. M., K. A. Beauchemin, and L. M. Rode. 2003. Effect of grain processing and silage on microbial protein synthesis and nutrient digestibility in beef cattle fed barley-based diets. J. Anim. Sci. 81:1057-1067.

Littell, R. C., G. A. Milliken, W. W. Stroup, and R. D. Wolfinger. 1996. SAS System for Mixed Models. SAS Inst. Inc., Cary, NC.

McAllister, T. A., R. C. Phillippe, L. M. Rode, and K.-J. Cheng. 1993. Effect of the protein matrix on the digestion of cereal grains by ruminal microorganisms. J. Anim. Sci. 71:205-212.

McCarthy, R. D., Jr., T. H. Klusmeyer, J. L. Vicini, J. H. Clark, and D. R. Nelson. 1989. Effects of source of protein and carbohydrate on ruminal fermentation and passage of nutrients to the small intestine of lactating cows. J. Dairy Sci. 72:2002-2016.

McCleary, B. V., V. Solah, and T. S. Gibson. 1994. Quantitative measurement of total starch in cereal flours and products. J. Cereal Sci. 20:51-58.

Moran, J. B. 1986. Cereal grains in complete diets for dairy cows: A comparison of rolled barley, wheat and oats and of three methods of processing oats. Anim. Prod. 43:27-36.

National Research Council. 2001. Nutrient Requirements of Dairy Cattle. 7th rev. ed. Natl. Acad. Sci., Washington, DC.

Nocek, J. E., and J. B. Russell. 1988. Protein and energy as an integrated system: Relationship of ruminal protein and carbohydrate availability to microbial synthesis and milk production. J. Dairy Sci. 71:2070-2107.

Nocek, J. E., and S. Tamminga. 1991. Site of digestion of starch in the gastrointestinal tract of dairy cows and its effects on milk yield and composition. J. Dairy Sci. 74:3598-3629.

Onetti, S. G., R. D. Shaver, M. A. McGuire, D. L. Palmquist, and R. R. Grummer. 2002. Effect of supplemental tallow on performance of dairy cows fed diets with different corn silage:alfalfa silage ratios. J. Dairy Sci. 85:632-641.

Orskov, E. R., C. Fraser, V. C. Mason, and S. O. Mann. 1970. Influence of starch digestion in the large intestine of sheep on caecal fermentation, caecal microflora and faecal nitrogen excretion. Br. J. Nutr. 24:671-682.

SAS Institute. 2004. SAS/STAT 9.1 User's Guide. SAS Inst., Inc., Cary, NC

Satter, L. D., and L. L. Slyter. 1974. Effect of ammonia concentration on rumen microbial protein production in vitro. Br. J. Nutr. 32:199-208.

Theurer, C. B., J. T. Huber, A. Delgado-Elorduy, and R. Wanderley. 1999. Summary of steam-flaking corn or sorghum grain for lactating dairy cows. J. Dairy Sci. 82:1950-1959.

Tommervik, R. S., and D. E. Waldern. 1969. Comparative feeding value of wheat, corn, barley, milo, oats and a mixed concentrate ration for lactating cows. J. Dairy Sci. 52:68-73.

Van Soest, P. J., J. B. Robertson, and B. A. Lewis. 1991. Methods for dietary fiber, neutral detergent fiber, and non-starch polysaccharides in relation to animal nutrition. J. Dairy Sci. 74:35933597.

Weatherburn, M. W. 1967. Phenol-hypochlorite reaction for determination of ammonia. Anal. Chem. 39:971-974.

Weiss, W. P., G. R. Fisher, and G. M. Erickson. 1989. Effect of source of neutral detergent fiber and starch on nutrient utilization by dairy cows. J. Dairy Sci. 72:2308-2315. 